\title{
Characterization of Genetic Diversity of Stone Fruit Rootstocks Used in Chile by Means of Microsatellite Markers
}

\author{
María José Arismendi \\ Programa Doctorado en Ciencias mención Biología Celular y Molecular Aplicada, Facultad de \\ Ciencias Agropecuarias y Forestales, Universidad de La Frontera, Avenida Francisco Salazar \\ \#01145, Temuco, Chile; and Centro de Estudios Avanzados en Fruticultura (CEAF), Av. Salamanca \\ s/n, km 105 Ruta 5 Sur, Sector Los Choapinos, Rengo, Chile
}

\author{
Patricio Hinrichsen \\ INIA CRI La Platina., Av. Santa Rosa \#11610, La Pintana, Santiago, Chile; and Centro de Estudios \\ Avanzados en Fruticultura (CEAF), Av. Salamanca s/n, km 105 Ruta 5 Sur, Sector Los Choapinos, \\ Rengo, Chile
}
Ruben Almada and Paula Pimentel
Centro de Estudios Avanzados en Fruticultura (CEAF), Av. Salamanca s/n, km 105 Ruta 5 Sur, Sector Los Choapinos, Rengo, Chile
Manuel Pinto
INIA CRI La Platina., Av. Santa Rosa \#11610, La Pintana, Santiago, Chile; and Centro de Estudios Avanzados en Fruticultura (CEAF), Av. Salamanca s/n, km 105 Ruta 5 Sur, Sector Los Choapinos, Rengo, Chile

\begin{abstract}
Boris Sagredo ${ }^{1}$
Centro de Estudios Avanzados en Fruticultura (CEAF) and INIA CRI Rayentué, Av. Salamanca s/n, km 105 Ruta 5 Sur, Sector Los Choapinos, Rengo, Chile
\end{abstract}

\begin{abstract}
Additional Index words. Prunus, SSR, genetic relationships, DNA fingerprinting
Abstract. Stone fruit (Prunus L.) production in Chile covers $\approx 43,000$ ha and includes a wide variety of soils and climates requiring a large diversity of rootstocks. The most commercially important rootstock cultivars are 26 genotypes from three different taxonomic groups belonging to the subgenera Amygdalus (L.) Benth. Hook. (peach group), Prunus Focke [= Prunophora (Neck.)] Focke (plum group), and Cerasus (Adans.) Focke (cherry group) with eight, seven, and 10 individuals, respectively. To determine their genetic diversity, characterization by microsatellite markers [simple sequence repeat (SSR)] was conducted. Of a total of 20 SSR markers evaluated, 12 generated amplified products that were consistent in the three taxonomic groups. The number of alleles per marker ranged from 18 for PSM-3 to four in CPPCT-002. Clustering analysis, by both traditional hierarchical and model-based approaches, indicate that all genotypes are clustered in their respective taxonomic groups, including the interspecific hybrids. Genetic diversity, measured as the average distances (expected heterozygosity) between individuals in the same cluster, was higher in Cerasus (0.78) followed by Prunus (0.72) and Amygdalus (0.64). Total number of alleles observed was 133, of which 14, 33, and 35 from six, 10, and 10 loci were unique for the peach, plum, and cherry rootstock groups, respectively. Alleles shared among peach/plum, plum/cherry, and peach/cherry rootstock genotypes were 13, 14, and 18 from nine, seven, and seven loci, respectively. Only six alleles from five loci were common to the three taxonomic groups. In addition, to develop a rootstock identification system based on SSR markers, a minimum set of three markers (PMS-3, BPPCT-037, and BPPCT-036) able to differentiate the 26 genotypes was identified. This study is the first step toward establishing a stone fruit rootstock breeding program in Chile.
\end{abstract}

\footnotetext{
Received for publication 27 June 2011. Accepted for publication 28 June 2012. This work was funded by grants from CEAF_R08I1001 and CONICYT and partially funded by grant FONDEF D04I-1060.

We acknowledge the CONICYT scholarships "Doctorado en Chile 2008 (21080351)" and "Apoyo para la Realización de Tesis Doctoral 2010 (24100126)," both to M.J. Arismendi. This article is part of M.J. Arismendi's doctoral degree dissertation from the Universidad de La Frontera, Temuco, Chile. We also thank María Herminia Castro from INIA La Platina for her assistance in developing this study.

${ }^{1}$ Corresponding author. E-mail: bsagredo@inia.cl.
}

Fruit production is one of the most dynamic and growing areas of Chilean agriculture. This country is one of the world's main fresh fruit producers and exporters and is first hemispherewide (Food and Agriculture Organization of the United Nations, 2006). Stone fruit production occupies $\approx 43,000$ ha (Instituto Nacional de Estadística, 2007) distributed in different regions of the country, which provides adequate climatic conditions with cold-hours and degree-days that allow early and late production of this type of fruit. However, because of a large diversity in 
soils, water availability, and general environmental conditions, a wide range of rootstocks is required, each of them with its particular characteristics adapted to different geographic regions and scion nature.

The Prunus genus is a highly diverse group of woody plants belonging to the Spiraeoideae subfamily of the Rosaceae family (Potter et al., 2007). Many species of this genus are economically important because they are a source of edible fruit, but various Prunus species are also used as rootstocks.

Rootstocks are responsible for water and nutrient absorption and must provide resistance to soil pathogens and pests as well as tolerance to the environment in which they develop. Many of the most important attributes of the fruit cultivars such as initial flowering, vigor, nutritional state, fruit production, size, and taste can be significantly influenced by the rootstock (Dozier et al., 1984; Jiménez et al., 2007; Zarrouk et al., 2005). Furthermore, the rootstock must be compatible with a wide range of cultivars to be grafted, be resistant to pest and diseases such as nematode and viruses, and be suited to different soil types (Layne, 1987). It is unlikely that any single Prunus genotype will have all these attributes. However, it is convenient to incorporate the maximum number of these characteristics to increase its usefulness and extend its area of adaptation.

The correct identification of Prunus rootstocks is a key requirement in activities associated with breeding programs and orchard production and management. The classical identification and characterization methods of fruit tree cultivars are based on morphology, cytology, or phytochemical traits, although these methods have some disadvantages such as high susceptibility to environmental factors and a low degree of polymorphism. The use of these traditional identification methods for rootstocks is even more limited because once the plants are grafted, any leaf, flower, or fruit characteristic is not visible (Liu et al., 2007; Serrano et al., 2002).

Using DNA markers is an effective and robust method to identify plant material because of its stability in different environmental conditions or in different tissues (Mathias et al., 2007). Methods based on DNA analysis have multiple advantages in providing precise genetic information from minimal amounts of tissues of any somatic organ independent of the plant's growth stage, allowing both short-term results and simultaneous analysis of a large number of samples.

Diverse types of molecular analysis have already been applied in Prunus with different markers such as isoenzymes (Mowrey and Werner, 1990), random fragment length polymorphism (Uematsu et al., 1991), random amplified polymorphic DNA (RAPD) (Casas et al., 1999), amplified fragment length polymorphism, SNPs (Fang et al., 2006), and SSR (Aranzana et al., 2003; Bouhadida et al., 2009; Lacis et al., 2009; Pedryc et al., 2009; Rojas et al., 2008). These have been widely used to characterize and classify commercial cultivars or estimate the genetic relationships among members of this genus. Among these, the microsatellite (SSR) markers are preferred because of their high level of polymorphism, codominant inheritance, abundance in the genome, transferability among species (most frequently in the same genus), and high reproducibility among laboratories. The potential of SSR markers to differentiate cultivars and study genetic relationships as well as its transferability among different Prunus species has been demonstrated by various authors (Aranzana et al., 2002, 2003; Dirlewanger et al., 2002; Downey and Iezzoni, 2000). Liu et al. (2007) and Serrano et al. (2002) successfully used SSR markers to fingerprint peach rootstocks.
The objective of this study was to conduct a molecular characterization of the main stone fruit rootstocks used in Chile to learn about their diversity, genetic relationships, and to identify the minimum number of markers required to establish a rational genotype identification system.

\section{Materials and Methods}

Plant material collection. Plant material was collected from four nurseries located in central Chile, including materials from the rootstock collection maintained at the Centro Regional de Investigación Rayentué of the Instituto de Investigaciones Agropecuarias in Rengo, Chile. This region is the most important stone fruit productive zone in Chile. A total of 26 Prunus rootstock genotypes were collected (Table 1). In accordance with similar taxonomic, morphological, and pedigree data available from databases, three groups were defined as 1) peach (Amygdalus subgenus); 2) plum (Prunus subgenus); and 3) cherry (Cerasus subgenus). It was not possible to assign the VC.13 accession to any group because we had no reference as to its origin.

Each sample was made up of four young apical leaves. Samples were obtained from certified mother plants, plants propagated in greenhouses, or plants in the field and being prepared for grafting according to nursery availability.

EXTRACTING GENOMIC DNA AND OBTAINING SIMPLE SEQUENCE REPEAT MARKERS. The genomic DNA of each sample was extracted according to the protocol described by Rojas et al. (2008). A panel of 20 SSR markers, previously described for different Prunus species (Aranzana et al., 2003; Dirlewanger et al., 2002), were used in this study, selected for their high discriminatory capacity and amplicon quality (Table 2). The polymerase chain reaction (PCR) was conducted in a final volume of $16 \mu \mathrm{L}$ containing $20 \mathrm{~mm}$ Tris- $\mathrm{HCl}(\mathrm{pH} 8.4), 50 \mathrm{~mm}$ $\mathrm{KCl}, 1.5 \mathrm{~mm} \mathrm{MgCl} 2,1 \mathrm{~mm}$ dNTPs, 50 pmol of each primer, $20 \mathrm{ng}$ of genomic DNA, and $0.5 \mathrm{U}$ of Taq polymerase (Stratagene Paq5000 DNA Polymerase; Agilent Technologies, Santa Clara, CA) with the following temperature profile: an initial $5 \mathrm{~min}$ at $95{ }^{\circ} \mathrm{C}, 35$ cycles of $30 \mathrm{~s}$ at $94{ }^{\circ} \mathrm{C}, 30 \mathrm{~s}$ at an annealing temperature in accordance with primers (Table 2), $30 \mathrm{~s}$ at $72{ }^{\circ} \mathrm{C}$, and finally, $5 \mathrm{~min}$ at $72{ }^{\circ} \mathrm{C}$. The PCR products were denatured by adding 0.5 volume of $95 \%$ formamide/dye solution (loading dye: 95\% deionized formamide, $10 \mathrm{~mm}$ EDTA, $0.1 \%$ xylene cyanol) and heated for $5 \mathrm{~min}$ at $94{ }^{\circ} \mathrm{C}$. Samples were then rapidly cooled on ice. Then $6 \mu \mathrm{L}$ of the denatured solution was loaded into $6 \%$ polyacrylamide gels containing $7.5 \mathrm{M}$ urea in $0.5 \mathrm{X}$ TBE buffer $(90 \mathrm{~mm}$ Tris, $90 \mathrm{~mm}$ boric acid, $2 \mathrm{~mm}$ EDTA). Electrophoresis was run for $2 \mathrm{~h}$ at $\approx 80 \mathrm{~W}$. Postelectrophoresis, visualization of the DNA fragments was carried out by silver staining according to Creste et al. (2001). Allele size was estimated by comparison with the molecular weight marker Gene Ruler ${ }^{\mathrm{TM}} 50$ bp DNA Ladder (Fermentas, Glen Burnie, MD).

DAta AnAlysis. First, the 20 SSR primer pairs included in this study were evaluated with regard to their transferability among the Prunus species used as rootstocks in Chile. Only those SSR markers that generated amplicons in all these Prunus species were selected for further analyses. In accordance with the taxonomic groups included in this study (Amygdalus, Prunus, and Cerasus), each SSR locus was characterized for the number of alleles (A) and the frequency of each allele. The genetic diversity and structure among distinct rootstock genotype groups was 
Table 1. Classification of Prunus rootstock accessions considered in this study in accordance with the subgenus to which they belong. ${ }^{\mathrm{z}}$

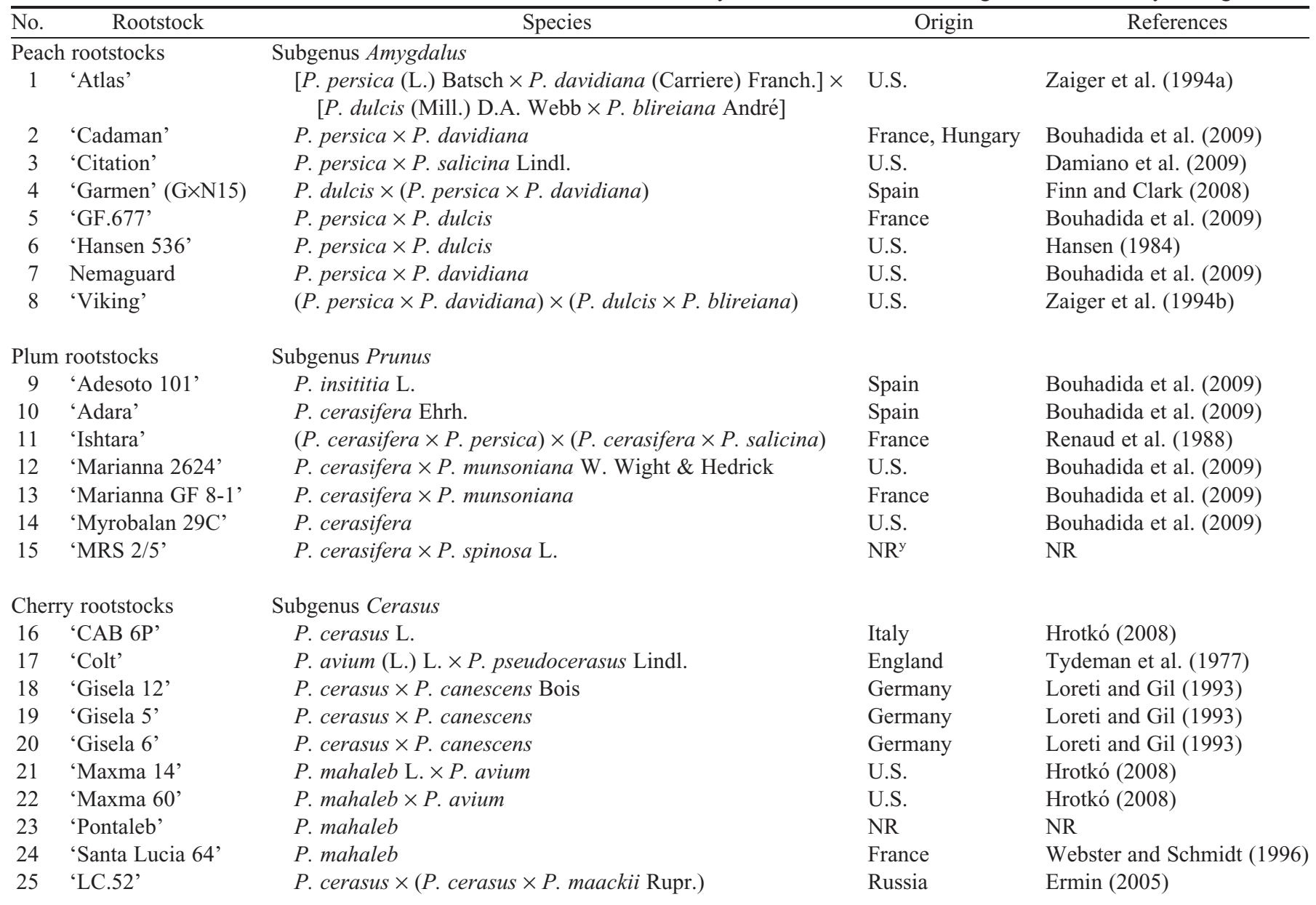

Unreferenced

26 VC.13

$\mathrm{NI}^{\mathrm{x}}$

NR

NR

${ }^{\mathrm{z}}$ The hybrid nature and species in their pedigrees are indicated for each one along with their (breeding) origin and references.

${ }^{\mathrm{y}} \mathrm{NR}=$ no references.

${ }^{\mathrm{x}} \mathrm{NI}=$ no information available.

estimated using both traditional hierarchical and model-based clustering methods. The hierarchical clustering was performed according to the following procedure: a binary matrix was constructed based on the presence/absence of microsatellite alleles. A similarity matrix was generated by the Dice coefficient (Nei and Li, 1979). Similarity index data were processed by the unweighted pair group with the mathematical averages method [unweighted pair group method with averages (UPGMA)], clustered with the DARwin software V5.0.158 (Perrier and Jacquemoud-Collet, 2006), and finally depicted in a dendrogram for rootstock grouping. Then the software Structure (University of Chicago, Chicago, IL) (Falush et al., 2003; Pritchard et al., 2000) was used to perform the modelbased clustering. The format for the data file was adjusted to the higher ploidy genotype, represented by Prunus insititia L. $(2 \mathrm{n}=$ 48) that is hexaploid. For genotypes with lower ploidy, the null alleles were coded as missing data (-9), and in the case of locus with recessive alleles, which did not amplify SSR products, they were represented with a value that was not observed at that locus but not missing (Falush et al., 2007). Considering that most of the rootstock genotypes included in this study are hybrids, the analysis was performed under admixture model using correlated allele frequencies with $\lambda=1.0$. Initially, the best $\mathrm{K}$ was inferred according to Evanno et al. (2005) running the program 20 times from $K=2$ to $K=10$ with 5000 burn-in steps before 20,000 MCMC repeats. Finally, the analysis was performed for $\mathrm{K}=2,3$, and 4 with 100,000 burn-in steps before $100,000 \mathrm{MCMC}$ repeats. Within this analysis, both identical and full-sib genotypes were eliminated and they were represented only for one genotype in each case.

To compare the efficiency of the markers in cultivar identification, we estimated discrimination power (D) of each primer as found in Tessier et al. (1999): Cj (confusion probability for the $j^{\text {th }}$ primer) is equal to the sum of the different c $i$ for all $I$ patterns generated by primer: $\mathrm{C} j=\sum c i=\sum p i(\mathrm{~N} p i-$ 1)/N-1 where $p i$ is the frequency of the $i^{\text {th }}$ allele and $\mathrm{N}$ is the number of individuals scored. Thus, the discriminating power of the $j^{\text {th }}$ primer is equal to: $\mathrm{D}=1-\mathrm{C}$. The total number of nondifferentiated pairs of cultivars for the $j^{\text {th }}$ primer is given by: $x j=$ $[\mathrm{N}(\mathrm{N}-1) / 2 \mathrm{Cj}]$. For a given combination of $k$ primers, $\mathrm{X} k$ (theoretical number of indistinguishable genotypes) is equal to: $\mathrm{X} k=\mathrm{N}(\mathrm{N}-1) / 2 \prod \mathrm{C} j$. 
Table 2. List of the 20 evaluated simple sequence repeat markers and their references, size range for amplicons, linkage group (LG), map position where they have been assigned, annealing temperature (Ta), and amplification quality of each Prunus group studied.

\begin{tabular}{|c|c|c|c|c|c|c|c|c|}
\hline Locus code & Reference & Size range $(b p)$ & LG & $\begin{array}{l}\text { Position } \\
\text { (cM) }\end{array}$ & $\mathrm{Ta}\left({ }^{\circ} \mathrm{C}\right)$ & Peach rootstock ${ }^{\mathrm{z}}$ & Plum rootstock ${ }^{\mathrm{z}}$ & Cherry rootstock $^{z}$ \\
\hline ВРPCТ-001 & Dirlewanger et al. (2002) & $125-195$ & G2 & 20.9 & 60 & ++ & ++ & $\mathrm{dr}$ \\
\hline ВРРСТ-008 & Dirlewanger et al. (2002) & $75-150$ & G6 & 30.1 & 59 & $\mathrm{dr}$ & $\mathrm{dr}$ & $\mathrm{dr}$ \\
\hline ВРРСТ-009 & Dirlewanger et al. (2002) & $145-200$ & G6 & 33.3 & 56 & $\mathrm{dr}$ & $\mathrm{dr}$ & ++ \\
\hline ВРPCТ-015 & Dirlewanger et al. (2002) & $150-180$ & G4 & 44.0 & 62 & ++ & - & ++ \\
\hline ВРРСТ-017 & Dirlewanger et al. (2002) & $125-220$ & G5 & 20.1 & 60 & ++ & ++ & ++ \\
\hline ВРРСТ-030 & Dirlewanger et al. (2002) & $160-200$ & G2 & 38.0 & 56 & ++ & ++ & - \\
\hline ВРPCТ-036 & Dirlewanger et al. (2002) & $125-175$ & G4 & 49.9 & 56 & ++ & ++ & ++ \\
\hline ВРРСТ-037 & Dirlewanger et al. (2002) & $112-190$ & G5 & 25.6 & 56 & ++ & ++ & ++ \\
\hline ВРРСТ-038 & Dirlewanger et al. (2002) & $125-175$ & G5 & 32.9 & 62 & ++ & ++ & $\mathrm{dr}$ \\
\hline ВРРСТ-039 & Dirlewanger et al. (2002) & $100-150$ & G3 & 18.0 & 56 & ++ & ++ & ++ \\
\hline ВРРСТ-040 & Dirlewanger et al. (2002) & $123-150$ & G4 & 18.4 & 56 & ++ & ++ & ++ \\
\hline СРРCТ-002 & Aranzana et al. (2002) & $92-108$ & G3 & 31.9 & 58 & ++ & ++ & ++ \\
\hline СРРCТ-005 & Aranzana et al. (2002) & $135-190$ & G4 & 10.4 & 58 & ++ & ++ & - \\
\hline СРРCТ-006 & Aranzana et al. (2002) & $180-250$ & G8 & 24.8 & 60 & ++ & ++ & ++ \\
\hline СРPCТ-022 & Aranzana et al. (2002) & $225-310$ & G3 & 31.9 & 58 & ++ & ++ & ++ \\
\hline СРРСТ-028 & Aranzana et al. (2002) & $100-130$ & G4 & 11.0 & 58 & ++ & ++ & - \\
\hline СРРСТ-029 & Aranzana et al. (2002) & $170-212$ & G1 & 65.1 & 56 & ++ & ++ & ++ \\
\hline СРРСТ-033 & Aranzana et al. (2002) & $125-175$ & G7 & 38.9 & 58 & ++ & ++ & ++ \\
\hline PMS-3 & Cantini et al. (2001) & $135-225$ & GN4 & 18.2 & 56 & ++ & ++ & ++ \\
\hline PMS-30 & Cantini et al. (2001) & $100-200$ & GN3 & 19.5 & 56 & ++ & ++ & ++ \\
\hline
\end{tabular}

$\overline{z_{+}+}=$good amplification; $\mathrm{dr}=$ bands difficult to resolve; $-=$ no amplification.

\section{Results and Discussion}

Characterization and Selection of Simple Sequence REPEAT MARKERS. The 20 SSR markers used in this study were evaluated in a population that contained 26 different Prunus genotypes belonging to three taxonomic groups and different subgenera (Amygdalus, Prunus, and Cerasus) described in Table 1. Of the total SSR loci evaluated, 18 generated amplicons in the peach rootstocks (Amygdalus subgenus), 17 generated products in the plum rootstock group (Prunus subgenus), and only 14 gave PCR products for the cherry rootstocks (Cerasus subgenus). The BPPCT-008, СРPCT-029, BPPCT-001, and CPPCT-022 markers had been previously described as able to amplify different Prunus species (Aranzana et al., 2002; Bouhadida et al., 2009; Dirlewanger et al., 2002). However, two of these markers (BPPCT-008 and BPPCT-001) resulted in faint bands that were difficult to resolve or did not amplify any group of genotypes at all (Table 2). Differences in amplification quality are because most of these SSR markers have been developed in peach [Prunus persica $(\mathrm{L}$.$) Batsch], and it is known$ that transferability varies among species of the same genus. Based on these results, only the 12 SSR that had good amplification quality for the three taxonomic groups were selected for further studies. These markers are distributed on seven chromosomes out of eight (one to five and seven to eight). None of the markers associated with chromosome 6 were selected. The markers BPPCT-008 and BPPCT-009, which map on that chromosome, generated amplification profiles that were difficult to resolve in three and two taxonomic groups, respectively (Table 2). The 12 selected markers amplified a total of 133 alleles in a range of 75 to $310 \mathrm{bp}$ in the three taxonomic groups. The number of alleles for each SSR marker varied largely from four (CPPCT-002) to 18 (PMS-3) (Table 3). The CPPCT-006 and CPPCT-033 markers included in this group of 12 SSRs had been previously selected by Mnejja et al. (2010) as part of the "universal Prunus set," which is an SSR markers set capable of amplifying any stone fruit species, including peach ( $P$. persica), european plum (P. domestica L.), sweet cherry ( $P$. avium L.), and almond [P. dulcis (Mill.) D.A. Webb] genotypes. However, these markers can also be used in other species and hybrids typically used as rootstocks.

For the eight genotypes of the peach rootstock group, we observed a mean of 4.3 alleles per locus, ranging from two (CPPCT-002) to eight (BPPCT-037). Allele frequency ranged from 0.70 to 0.06 with a mean of 0.25 . The CPPCT-002 marker amplified two alleles, and one of these was overrepresented with $p i=0.75$; in the case of CPPCT-006, three alleles were amplified and one was also overrepresented with the same frequency ( $p i=0.75$ ). Taking into account all the loci, the observed mean heterozygosity (Ho) was 0.59 , which ranged from 0.13 for BPPCT-039 to 1.0 for BPPCT-037, CPPCT-029, and PMS-30. These parameters are higher than the reported mean values for SSR markers in peaches (Aranzana et al., 2003; Bouhadida et al., 2007a), but similar to those obtained by Bouhadida et al. (2009) in the characterization of a particular set of peach rootstocks. In the case of plum and cherry rootstocks, ploidy levels are not always known with accuracy because there are different levels within the same group of rootstocks (Bouhadida et al., 2007b). Furthermore, it is difficult to estimate SSR marker allelic dose in triploid and tetraploid individuals. Therefore, only the number of alleles per locus was estimated for the Prunus and Cerasus groups (Table 3). The plum group, made up of seven genotypes, showed a range of one (CPPCT029) to nine (BPPCT-040) alleles per locus. In the case of the cherry group, made up of 11 genotypes, the number of alleles per locus varied from two (CPPCT-002) to 11 (PMS-3). The distribution of total alleles amplified from the 12 selected SSR loci are shown in Figure 1. Of a total of 133 alleles, 14, 33, and 35 (from six, 10, and 10 SSR markers) were unique alleles for the peach, plum, and cherry groups, respectively. Most of them 


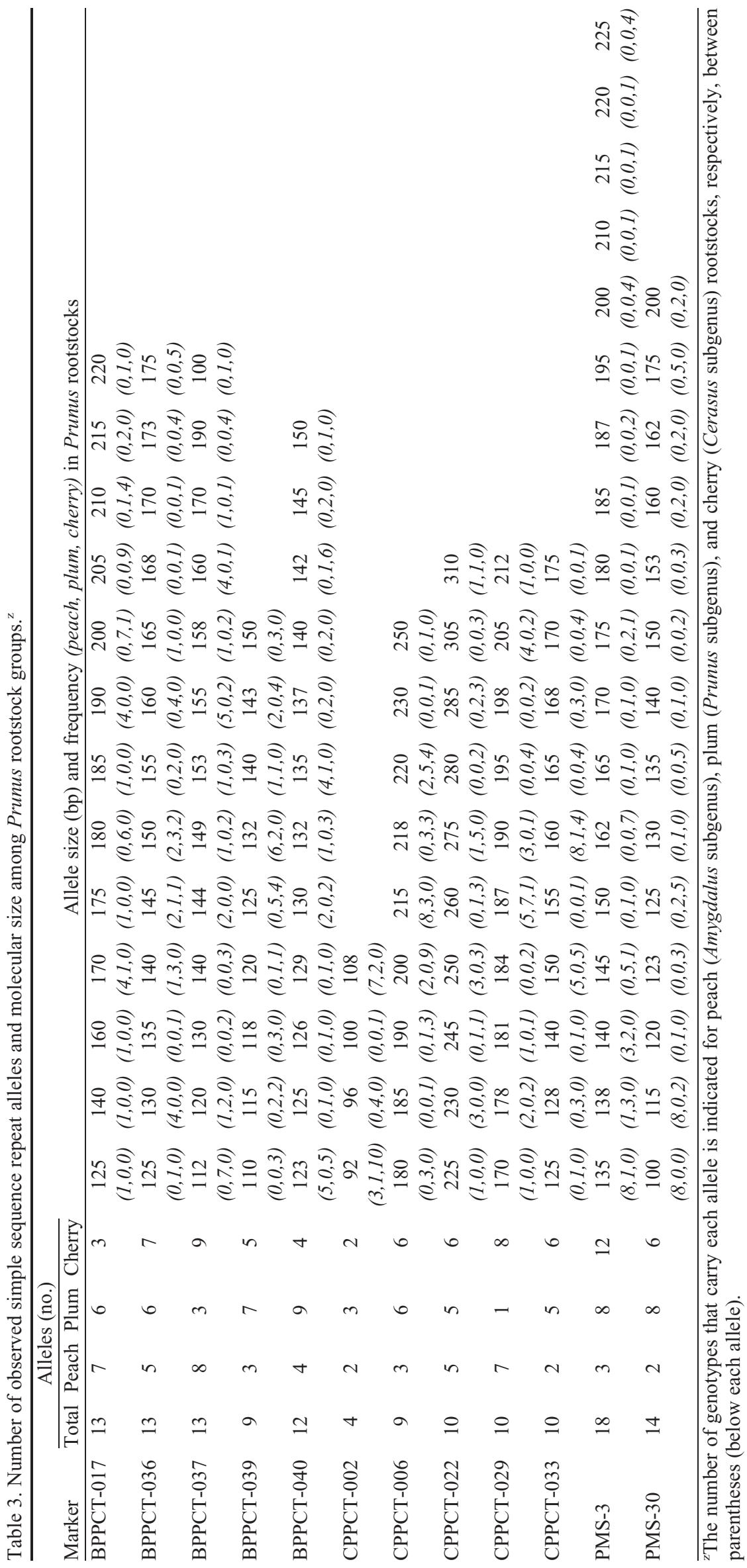


exhibited a low frequency (less than 0.15); however, some exhibited a high frequency such as alleles of loci PMS-30 and BPPCT-037 that were present in every genotype of the peach and plum taxonomic groups. The BPPCT-017 alleles present in cherry rootstocks were the same in $90 \%$ of the genotypes. Figure 1 also shows the number of alleles shared between pairs of taxonomic groups with 13, 18, and 14 (from nine, seven, and seven SSR loci) for peach/plum, peach/cherry, and plum/cherry

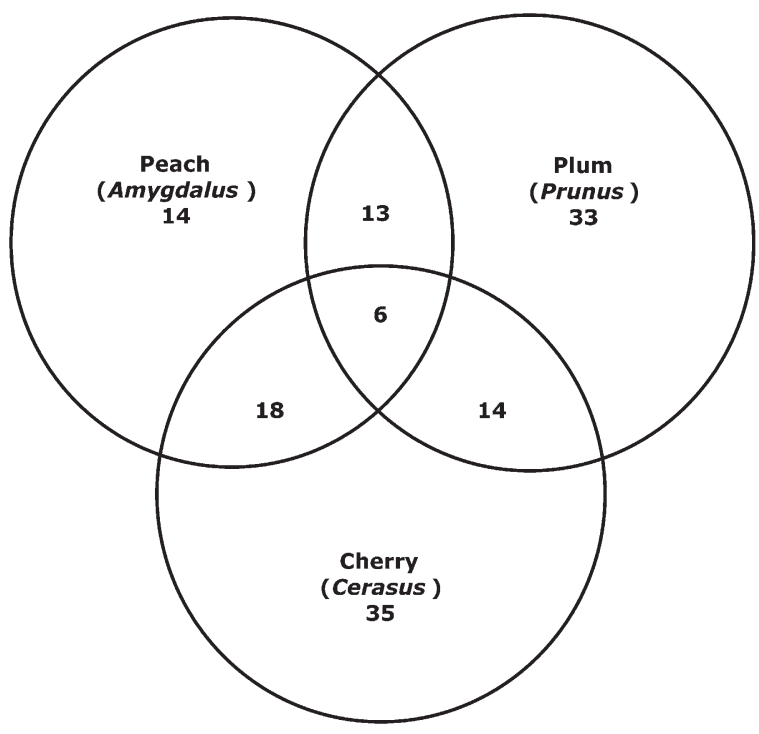

Fig. 1. Allele distribution among sub-genera of Prunus rootstocks from 12 simple sequence repeat loci. pairs, respectively. An increase in the frequency of shared alleles can be seen in the peach and plum rootstock groups because of the presence of intersubgenus hybrids such as 'Citation' and 'Ishtara' that contain $P$. salicina Lindl. and $P$. persica in their genetic background, respectively. Only six alleles belonging to five markers (BPPCT-036, СРPCT-002, СРPCT-006, СРРCT029, and CPPCT-033) were shared among the three taxonomic groups.

Genetic diversity and structure of the Prunus RоOтSTOCKS. Based on the 133 alleles generated by the 12 selected SSR markers, genetic diversity was estimated for the 26 Prunus rootstocks most commonly found in Chile using both traditional hierarchical clustering and model-based clustering methods. For the hierarchical clustering, using the Dice coefficient as a genetic distance index and UPGMA as the clustering method, a dendrogram was generated (Fig. 2). The generated clusters coincide with the three taxonomic groups (Amygdalus, Prunus, and Cerasus subgenera) and their respective hybrids, all of which were previously defined based on botanical and pedigree information. The VC.13 accession of unknown origin was found to be indistinguishable from the 'LC.52' hybrid genotype $[P$. cerasus L. $\times(P$. cerasus $\times P$. maackii Rupr. $)]$ of Russian origin (Table 1). Similar results were obtained by the model-based clustering approach using Structure software (Fig. 3A) under the admixture model with correlated allele frequencies. Based on the second order rate of change of the likelihood $(\Delta \mathrm{K})$ according to Evanno et al. (2005), the best inferred value of the true number of structured populations was $\mathrm{K}=3$ (Fig. 3B). These results are concordant with Odong et al. (2011), who compared the performance of hierarchical clustering with the model-based clustering methods showing the usefulness

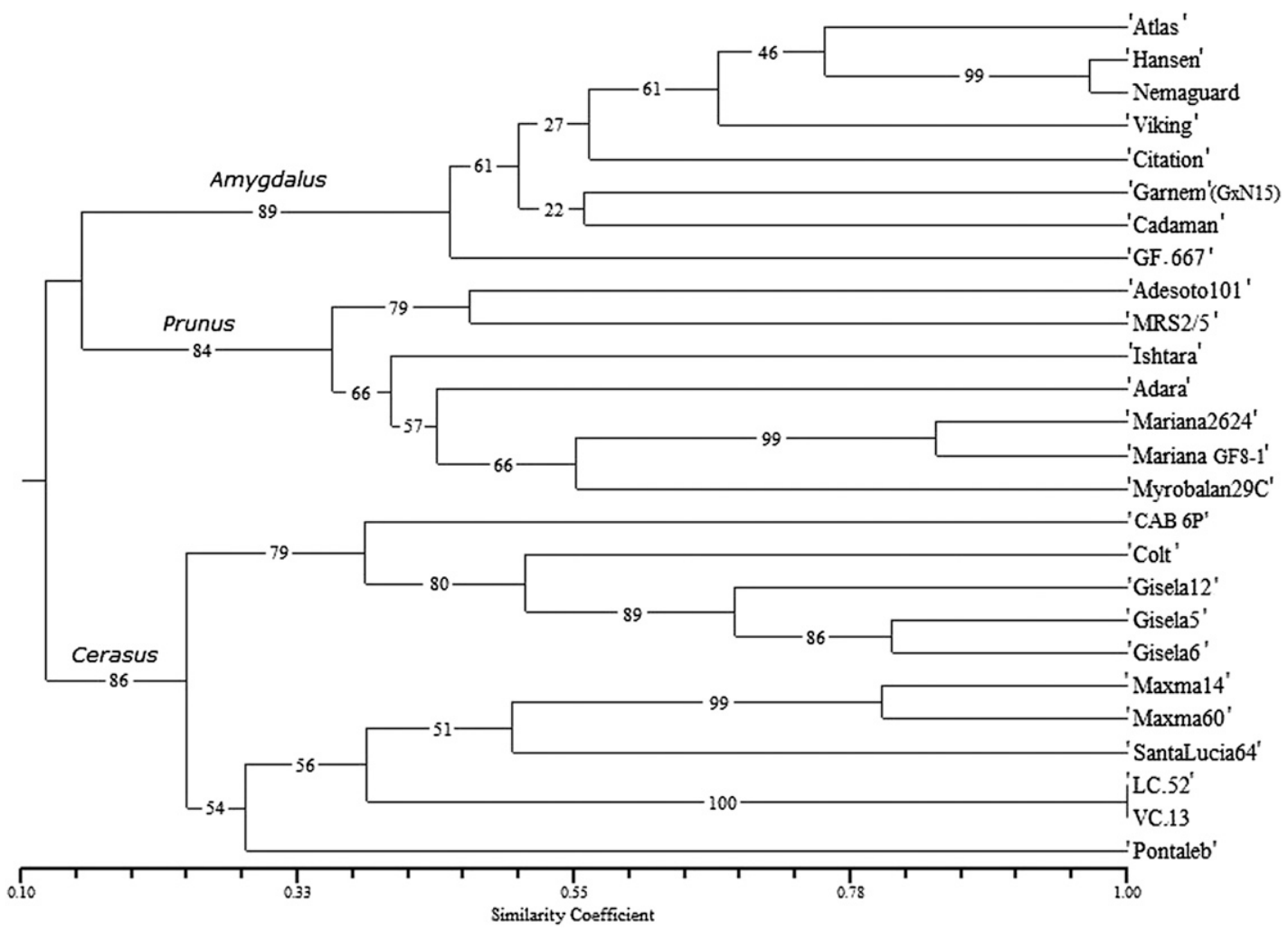

Fig. 2. Traditional hierarchical clustering analysis of 26 Prunus rootstocks used in Chile based on their allelic variation at 12 simple sequence repeat loci. 


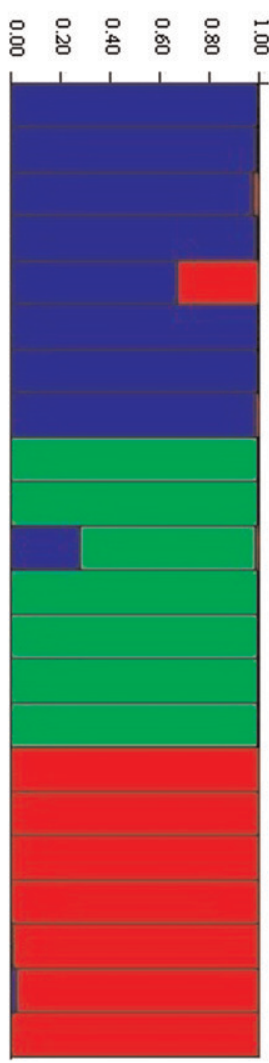

$\mathrm{K}=\mathbf{3}$
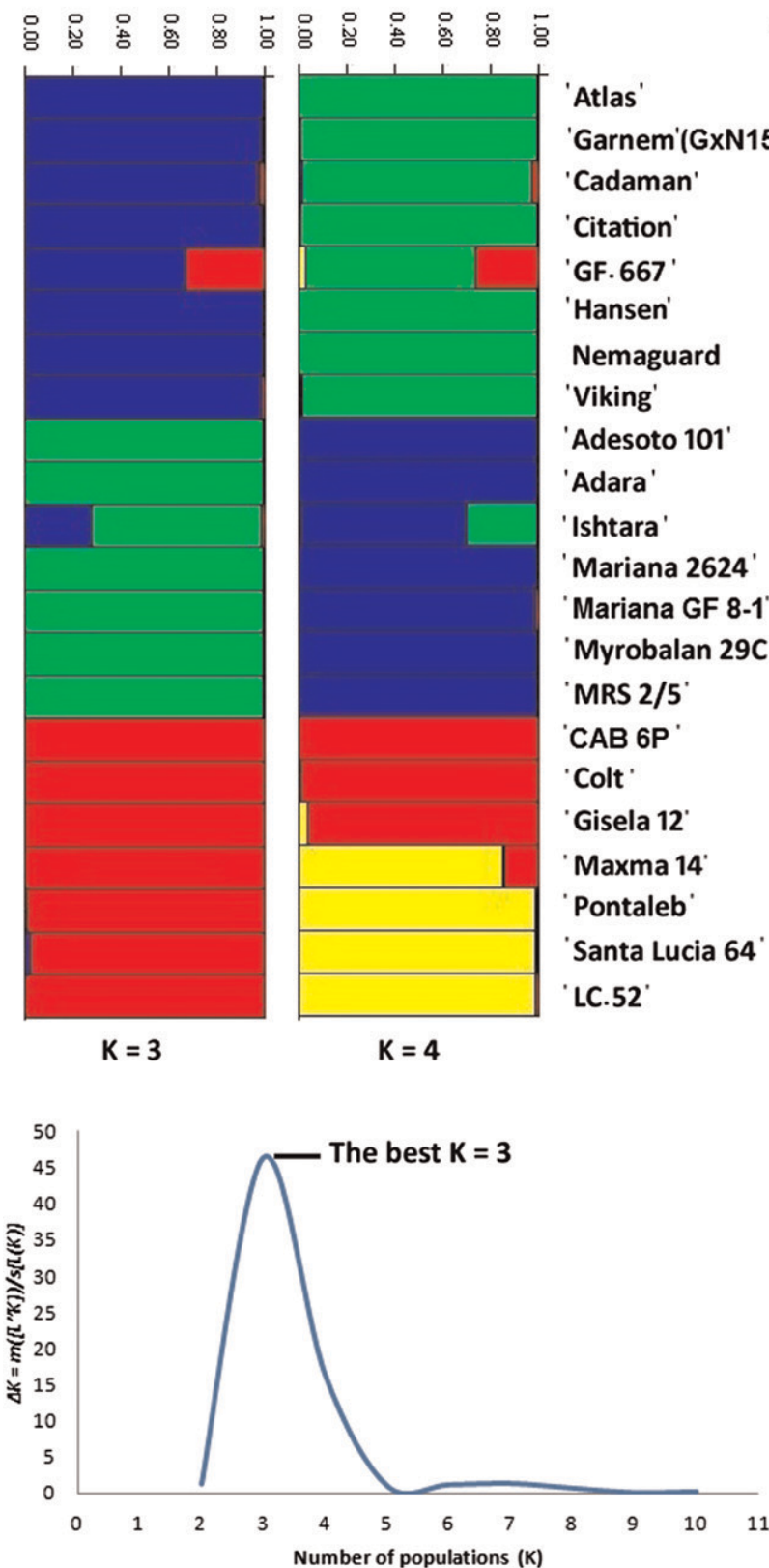

Fig. 3. Model-based clustering analysis using STRUCTURE software. (A) Inferred structure for three $(\mathrm{K}=3)$ and four $(\mathrm{K}=4)$ populations. (B) The best $K$ calculated based on the second order rate of change of the likelihood $(\Delta K)$ (Evanno et al., 2005).

and validity of using traditional techniques for the genetic analysis of germplasm collections, but most inferences about population structures are reduced to a visual interpretation. In the case of model-based clustering methods, they are statistically more robust to make inferences about presence of population structure, identifying distinct genetic populations, assigning individuals to populations, and/or identifying migrants and admixed individuals (Falush et al., 2003, 2007; Pritchard et al., 2000).

The genetic diversity, at the best $\mathrm{K}=3$, measured as the average distances (expected heterozygosity) between individuals in the same cluster, was higher in Cerasus (0.78) with seven genotypes. Identical as 'LC.52' and VC.13 and full-sib genotypes as Gisela and Maxma were represented by one genotype each. This cluster, at $\mathrm{K}=4$, was divided into two groups, one including the Maxma hybrid family $(P$. mahaleb L. $\times P$. avium $)$ and one including the Gisela hybrid family ( $P$. cerasus $\times$ $P$. canescens Bois.). In addition to the natural differences among species within the Cerasus subgenus, the observed division reflects the type of materials that breeders manage in their programs. The subgenera Prunus (seven genotypes) and Amygdalus (eight genotypes) follow in ascending order of expected heterozygosity ( 0.72 and 0.64 , respectively). Consequently, the order of differentiation coefficients $\left(\mathrm{F}_{\mathrm{st}}\right)$, from the putative ancestral population, is inverse, where Amydalus subgenus present the higher (0.301) followed by Prunus $(0.208)$ and Cerasus (0.132).

Materials of the plum (Prunus) group potentially contain alleles of six different species of the Prunus subgenus, even including $P$. persica background ('Ishtara'). Accessions in the peach rootstock potentially contain alleles of five species of the Amygdalus subgenus, including $P$. salicina of the plum group ('Citation'). Within the Prunus subgenus, the 'Mariana GF 8-1' ('GF.8-1') and 'Mariana 2624' ('M.2624') were the most closely related genotypes followed by 'Myrobalan 29C' ('M.29C') (Fig. 2). These results coincide with those obtained by Bouhadida et al. (2009), who found a high proximity among these genotypes, a relationship that is also correlated with their morphological similarity. Day (1953) had already reported a high similarity between 'GF.8-1', 'M.2624', and 'M.29C'; the same author put forward some doubts about their relationship with American wild plum (P. munsoniana $\mathrm{W}$. Wight \& Hedrick), which should be one of the progenitor of 'GF.8-1' and 'M.2624'. Furthermore, Bouhadida et al. (2009) stated that 'M.2624', 'GF 8-1', and 'M.29C' share four alleles in four loci that are absent in the rest of the plum rootstock group studied and which support the high degree of similarity found among these genotypes. Casas et al. (1999) and Serrano et al. (2002) also reported a very close relationship between 'M.29C' and 'M.2624' using RAPD and SSR markers.

Discrimination POWER OF SSR MARKERS. To determine the optimum SSR combination to identify rootstock cultivars, SSR markers were arranged according to the number of differentiated genotypes. It can be observed in Table 4 that each marker was evaluated depending on the value of its discrimination power (D). This parameter is frequently used to measure the

Table 4. Confusion probability $\left(C_{j}\right)$, primer discrimination power $\left(D_{j}\right)$, and number of observed genotypes for each of the 12 simple sequence repeat markers analyzed for 26 Prunus rootstocks.

\begin{tabular}{|c|c|c|c|}
\hline Marker & $\mathrm{Cj}$ & $\mathrm{Dj}$ & Observed genotypes (no.) \\
\hline PMS-3 & 0.05 & 0.95 & 15 \\
\hline ВРРСТ-037 & 0.06 & 0.94 & 14 \\
\hline ВРРСТ-036 & 0.08 & 0.92 & 13 \\
\hline СРРСТ-022 & 0.08 & 0.92 & 13 \\
\hline PMS-30 & 0.08 & 0.92 & 13 \\
\hline ВРРCТ-040 & 0.10 & 0.90 & 12 \\
\hline ВРРCТ-039 & 0.11 & 0.89 & 11 \\
\hline ВРРСТ-017 & 0.11 & 0.89 & 11 \\
\hline СРРCТ-006 & 0.15 & 0.85 & 10 \\
\hline СРРCТ-033 & 0.15 & 0.85 & 10 \\
\hline СРРСТ-029 & 0.16 & 0.84 & 9 \\
\hline СРРСТ-002 & 0.36 & 0.64 & 6 \\
\hline
\end{tabular}


discriminatory capacity of SSR markers (Mathias et al., 2007; Rojas et al., 2008; Tessier et al., 1999); however, its value can vary for the same SSR depending on the characteristics of the germplasm studied (Tessier et al., 1999). Calculated discrimination power can vary between 0 and 1 in which the value closest to 1 indicates a higher level of polymorphism or variation. The estimate of this parameter is based on both allelic frequencies and polymorphic information content (PIC), and values obtained by any of these approaches are practically identical (Tessier et al., 1999). Because this study deals with accessions with different ploidy levels, we chose the allele frequency rather than estimated PIC. The last, which is based on heterozygosity values, is very difficult to estimate in a population with unknown ploidy mixture and levels. The PMS-3 marker generated the largest number of observed genotypes $(n=15)$ and alleles $(n=18)$. The marker with the lowest value for both parameters was CPPCT-002 with only six observed genotypes and four alleles. The discrimination power of SSRs was always greater than 0.50; the CPPCT-002 marker had the lowest value because it has the fewest polymorphic loci and $\mathrm{D}=0.64$. The observed mean value was high $(0.88)$, comparable to 0.75 obtained by Bouhadida et al. (2009) for peach rootstocks and 0.64 by Aranzana et al. (2003) for peach cultivars. For identification purposes, the recommendation of including the largest possible number of parameter descriptors is also valid in the case of use of molecular markers such as SSR (Mathias et al., 2007). However, to reduce costs and increase overall analysis efficiency, it is necessary to identify a minimum number of markers with a very low risk of confusion (Narvaez et al., 2001). Markers included in this analysis were arranged from top to bottom according to their discriminatory power and then combined by adding them one by one in the same order with the objective of defining a highly informative group of markers that allows differentiating every accession under scrutiny. The theoretical number of indistinguishable genotypes $(\mathrm{X} k)$ was determined for each marker combination and a population of $\mathrm{n}=26$. Thus, when PMS-3 is used alone, 11 indistinguishable genotypes were obtained with a number that decreased to 0.8 when a new marker was added to the analysis (ВРPCT-037). Finally, $\mathrm{X} k$ decreased to 0.07 when adding any of the remaining markers arranged according to their discrimination power. Therefore, combining only three of the markers considered would be sufficient to discriminate all the rootstock genotypes being studied. Except for CPPCT-002, they all have high discrimination power, which confirms their efficiency in identifying cultivars of the Prunus genus.

Results can be compared with those reported by Aranzana et al. (2003), who were able to differentiate $87 \%$ of the 212 peach cultivars of European origin with 16 SSRs. These values indicate that peaches and nectarines $[P$. persica var. nucipersica (Suckow) C.K. Schneid.] have a significantly lower genetic diversity compared with cultivars used for rootstocks. However, results are similar to those obtained in other fruit species in which 66 apple (Malus domestica Borkh.) cultivars (excluding cultivars derived from mutations such as Fuji or Gala) were discriminated by using only four SSR markers (Galli et al., 2005). In the case of sweet cherry, 68 cultivars representing $90 \%$ of the studied population were discriminated by nine SSR markers (Wunsch and Hormaza, 2002), whereas 224 grape (Vitis vinifera L.) cultivars were differentiated using eight markers by combining six RAPD and two SSR (Tessier et al., 1999). Similar to our study, Bouhadida et al. (2009) discriminated 44 genotypes of Prunus rootstocks with only three SSR (BPPCT-001, CPPCT-022, and UDP98-407). Seven RAPD markers were selected in the same genotype group by Casas et al. (1999), but they could not differentiate some of the plum rootstock clones, which in turn were differentiated by two of the mentioned markers (BPPCT001 and UDP98-407). It is interesting to note that the markers in this study, identified as the most informative, were different from those evaluated and selected by Bouhadida et al. (2009); the reason for this might be in the different sets of rootstock cultivars considered in each case, and in this sense, both studies are complementary.

This molecular characterization of the 26 most used rootstock genotypes in Chile using 12 SSR markers has generated relevant information related to the genetic relationships and diversity existing among different Prunus sp. taxonomic groups. Hence, it is the first course of action toward establishing a modern genetic breeding program for stone fruit rootstocks in Chile.

\section{Literature Cited}

Aranzana, M., J. García-Mas, J. Carbó, and P. Arús. 2002. Development and variability analysis of microsatellite markers in peach. Plant Breed. 121:87-92.

Aranzana, M., A. Pineda, P. Cosson, E. Dirlewanger, J. Ascasibar, G. Cipriani, C. Ryder, R. Testolin, A. Abbott, G. King, A. Iezzoni, and P. Arús. 2003. A set of simple-sequence repeat (SSR) markers covering the Prunus genome. Theor. Appl. Genet. 106:819-825.

Bouhadida, M., A.M. Casas, M.J. Gonzalo, P. Arús, M.A. Moreno, and Y. Gogorcena. 2009. Molecular characterization and genetic diversity of Prunus rootstocks. Sci. Hort. 120:237-245.

Bouhadida, M., A.M. Casas, M.A. Moreno, and Y. Gogorcena. 2007a. Molecular characterization of Miraflores peach variety and relatives using SSRs. Sci. Hort. 111:140-145.

Bouhadida, M., J.P. Martín, G. Eremin, J. Pinochet, M.A. Moreno, and Y. Gogorcena. 2007b. Chloroplast DNA diversity in Prunus and its implication on genetic relationships. J. Amer. Soc. Hort. Sci. 132: 670-679.

Cantini, C., A. Iezzoni, W. Lamboy, M. Boritzki, and D. Struss. 2001. DNA fingerprinting of tetraploid cherry germplasm using simple sequence repeats. J. Amer. Soc. Hort. Sci. 126:205-209.

Casas, A., E. Igartua, G. Balaguer, and M. Moreno. 1999. Genetic diversity of Prunus rootstocks analyzed by RAPD markers. Euphytica 110:139-149.

Creste, S., A. Tulmann-Neto, and A. Figueira. 2001. Detection of simple sequence repeats polymorphisms in denaturating polyacrylamide sequencing gels by silver staining. Plant Mol. Biol. Rpt. 19: 299-306.

Damiano, C., G. Delia, A. Frattarelli, L. Farina, and M. Buccheri. 2009. In vitro multiplication, rooting, acclimatization and related protein profiles of rootstock 'Citation' (Prunus saliciana $\times$ Prunus persica). Acta Hort. 812:349-358.

Day, L.H. 1953. Rootstocks for stone fruits. California Agr. Expt. Sta. Bull. 736.

Dirlewanger, E., P. Cosson, M. Tavaud, M.J. Aranzana, C. Poizat, A. Zanetto, P. Arús, and F. Laigret. 2002. Development of microsatellite markers in peach [Prunus persica (L.) Batsch] and their use in genetic diversity analysis in peach and sweet cherry (Prunus avium L.). Theor. Appl. Genet. 105:127-138.

Downey, S. and A. Iezzoni. 2000. Polymorphic DNA marker in black cherry (Prunus serotina) are identified using sequences for sweet cherry, peach and sour cherry. J. Amer. Soc. Hort. Sci. 125:26-30.

Dozier, W.A., J.W. Knowles, and C.C. Carlton. 1984. Survival, growth and yield of the peach trees as affected by rootstock. HortScience 19:26-30.

Ermin, G. 2005. Prunus plant named 'LC 52' Vol. US PP16, 114 P3. U.S. Patent and Trademark Office, Washington, DC. 
Evanno, G., S. Regnaut, and J. Goudet. 2005. Detecting the number of clusters of individuals using the software STRUCTURE: A simulation study. Mol. Ecol. 14:2611-2620.

Falush, D., M. Stephens, and J.K. Pritchard. 2003. Inference of population structure: Extensions to linked loci and correlated allele frequencies. Genetics 164:1567-1587.

Falush, D., M. Stephens, and J.K. Pritchard. 2007. Inference of population structure using multilocus genotype data: Dominant markers and null alleles. Mol. Ecol. Notes 7:574-578.

Fang, J., T. Twito, Z. Zhang, and C.T. Chao. 2006. Genetic relationships among fruiting-mai (Prunus mume Sieb. et Zucc) cultivars evaluated with AFLP and SNP markers. Genome 49: 1256-1264.

Finn, C.E. and J.R. Clark. 2008. Register of new fruit and nut cultivars, List 44. HortScience 43:1321-1343.

Food and Agriculture Organization of the United Nations. 2006. FAO statistical yearbook 2005-2006. FAO, Rome, Italy.

Galli, Z., G. Halasz, E. Kiss, and L. Heszky. 2005. Molecular identification of commercial apple cultivars with microsatellite markers. HortScience 40:1974-1977.

Hansen, C.J. 1984. Almond $\times$ peach hybrid rootstock tree (Hansen 2168), Vol. Plant 5,210. U.S. Patent and Trademark Office, Washington, DC.

Hrotkó, K. 2008. Progress in cherry rootstock research. Acta Hort. 795:171-178.

Instituto Nacional de Estadística. 2007. VII Censo Nacional Agropecuario y Forestal. Instituto Nacional de Estadística, Santiago, Chile.

Jiménez, J., J. Pinochet, Y. Gogorcena, J.A. Betran, and M.A. Moreno. 2007. Influence of different vigour cherry rootstock on leaves and shoot mineral composition. Sci. Hort. 112:73-79.

Lacis, G., I. Rashal, S. Ruisa, V. Trajkovski, and A.F. Iezzoni. 2009. Assessment of genetic diversity of Latvian and Swedish sweet cherry (Prunus avium L.) genetic resources collections by using SSR (microsatellite) markers. Sci. Hort. 121:451-457.

Layne, R.E.C. 1987. Peach rootstock. Rootstock for fruits crops. Wiley, New York, NY.

Liu, X., G. Reighard, G.A. Swire-Clark, and W.V. Baird. 2007. Peach rootstock identification by DNA-fingerprinting with microsatellite (SSR) markers. J. Amer. Pomol. Soc. 61:162-166.

Loreti, F. and G. Gil. 1993. Los portainjertos del ciruelo y del cerezo: Presente y futuro. Revista Frutícola 14:103-111.

Mathias, M., B. Sagredo, and J. Kalazich. 2007. Use of SSR markers to identify potato germplasm in the INIA Chile breeding program. Chilean J. Agr. Res. 67:3-15.

Mnejja, M., J. García-Mas, J.M. Audergon, and P. Arús. 2010. Prunus microsatellite marker transferability across rosaceous crops. Tree Genet. Genomes 6:689-700.

Mowrey, B.D. and D.J. Werner. 1990. Phylogenetic relationships among species of Prunus as inferred by isozyme markers. Theor. Appl. Genet. 80:129-133.

Narvaez, C., H. Castro, J. Valenzuela, and P. Hinrichsen. 2001. Patrones genéticos de los cultivares de vides de vinificación más comúnmente usados en Chile basados en marcadores microsatélites. Chilean J. Agr. Res. 61:249-261.
Nei, M. and W. Li. 1979. Mathematical model for studying genetic variation in terms of restriction endonucleases. Proc. Natl. Acad. Sci. USA 76:5269-5273.

Odong, T.L., J. Heerwaarden, J. Jansen, T.J.L. Hintum, and F.A. Eeuwijk. 2011. Determination of genetic structure of germplasm collections: Are traditional hierarchical clustering methods appropriate for molecular marker data? Theor. Appl. Genet. 123:195-205.

Pedryc, A., S. Ruthner, R. Hermán, B. Krska, A. Hegedüs, and J. Halász. 2009. Genetic diversity of apricot revealed by a set of SSR markers from linkage group G1. Sci. Hort. 121:19-26.

Perrier, X. and J.P. Jacquemoud-Collet. 2006. DARwin software. 10 July 2011. <http://darwin.cirad.fr/>.

Potter, D., T. Eriksson, R.C. Evans, S. Oh, J.E.E. Smedmark, D.R. Morgan, M. Kerr, K.R. Robertson, M. Arsenault, T.A. Dickinson, and C.S. Campbell. 2007. Phylogeny and classification of Rosaceae. Plant Syst. Evol. 266:5-43.

Pritchard, J.K., M. Stephens, and P. Donnelly. 2000. Inference of population structure using multilocus genotype data. Genet. 155:945-959.

Renaud, R., R. Bernhard, C. Grasselly, and F. Dosba. 1988. Diploid plum $\times$ peach hybrid rootstock for stone fruit trees. HortScience 23:115-116.

Rojas, G., M. Méndez, C. Muñoz, G. Lemus, and P. Hinrichsen. 2008. Identification of a minimal microsatellite marker panel for the fingerprinting of peach and nectarine cultivars. Electronic J. Biotechnol. 11. DOI: $10.2225 /$ vol11-issue 5-fulltext-1.

Serrano, B., J. Gómez-Aparisi, and J.I. Hormaza. 2002. Molecular fingerprinting of Prunus rootstock using SSR. J. Hort. Sci. Biotechnol. 77:368-372.

Tessier, C., J. David, P. This, J.M. Boursiquot, and A. Charrier. 1999. Optimization of the choice of molecular markers for varietal identification in Vitis vinifera L. Theor. Appl. Genet. 98:171-177.

Tydeman, H.M., E.M. Tydeman, and W.M. Tydeman. 1977. Cherry rootstock-COLT variety Vol. Plant 4,059. U.S. Patent and Trademark Office, Washington, DC.

Uematsu, C., T. Sasakuma, and Y. Ogihara. 1991. Phylogenetic relationships in the stone fruit group of Prunus as revealed by restriction fragment analysis of chloroplast DNA. Jpn. J. Genet. 66:59-69.

Webster, A. and H. Schmidt. 1996. Rootstock for sweet and sour cherries, p. 127-163. In: Webster, A.D. and N.E. Looney (eds.). Cherries: Crop physiology, production and uses, CAB International, Wallingford, UK.

Wunsch, A. and J.I. Hormaza. 2002. Molecular characterization of sweet cherry (Prunus avium L.) genotypes using peach [Prunus persica (L.) Batsch.] SSR sequences. Heredity 89:56-63.

Zaiger, C.F., G.N. Zaiger, and L.M. Gardener. 1994a. Interspecific rootstock tree "ATLAS" Vol. Plant 8,913. U.S. Patent and Trademark Office, Washington, DC.

Zaiger, C.F., G.N. Zaiger, L.M. Gardner, and G.G. Zaiger. 1994b. Interspecific rootstock "VIKING" Vol. Plant 8,912. U.S. Patent and Trademark Office, Washington, DC.

Zarrouk, O., Y. Gogorcena, J. Gómez-Aparisi, J. Betrán, and M. Moreno. 2005. Influence of almond $\times$ peach hybrids rootstock on flower and leaf mineral concentration, yield and vigour of two peach cultivars. Sci. Hort. 106:502-514. 